spring, an in situ subice sampling method which encloses the algal sample before disturbance gives higher biomass estimates than SIPRE coring. The SCC is the instrument of choice for mid to late season because it is fast, accurate, and inexpensive. However, because of suction-line freezing problems, SIPRE cores may still be preferable below $\approx-30^{\circ} \mathrm{C}$. Diver-operated devices are very good but require a sophisticated and costly ice-diving program. Nevertheless the ability to visually verify remotely obtained results, and to callbrate other techniques, may make diving worthwhile.

\section{Acknowledgements}

We thank P. Amarualik, D. Hamilton, S. Himmer, J. Butler, and E. Schindler for assistance in the field. The Bedford Institute of Oceanography provided the SIPRE corer. I. Davies, G. Cota, and an anonymous reviewer made helpful comments on the manuscript.

\section{References}

ANONYMOUS. 1974. History, development, performance and description of
USA-CRELL $3^{\prime \prime}$ coring auger. Available from Geotest Instrument Corp., Box 551, Wheeling, IL 60090, USA.

Apollonio, S. 1965. Chlorophyll in arctic sea ice. Arctic 18: 118-122.

BUNT, J. S., AND C. S. LEE. 1970. Seasonal primary production in Antarctic sea ice at McMurdo Sound in 1967. J. Mar. Res. 28: 304-320.

CoTA, G. F. 1985. Photoadaptation of high Arctic ice algae. Nature (Lond.) 315: $219-222$.

Gosselin, M., L. Legendre, S. Demers, AND R. G. INGRAM. 1985. Responses of sea-ice microalgae to climate and fortnightly tidal energy inputs (Manitounuk Sound, Hudson Bay). Can. J. Fish. Aquat. Sci. 42: 999-1006.

MEguro, H., K. Ito, AND H. Funushima. 1967. Ice flora (bottom type): a mechanism of primary production in polar seas and the growth of diatoms in sea ice. Arctic 20: 114-133.

NEWBURY, T. R. 1983. Under landfast ice. Arctic 36: 328-340.

Palmisano, A. C., AND C. W. Sullivan. 1983. Sea ice microbial communities (SIMCO). 1. Distribution, abundance, and primary production of ice microalgae in McMurdo Sound, Antarctica in 1980. Polar Biol. 2 . 171-177.

Stainton, M. P., M. J. CAPEL, AND F. A. J. ARMSTrong. 1977. The chemical analysis of freshwater. 2nd ed. Can. Fish. Mar. Serv. Misc. Spec. Publ. 25: vi $+180 \mathrm{p}$.

Welch, H. E., AND M. A. BergmanN. 1985. Winter respiration of lakes at Saqvaqjuac, N.W.T. Can. J. Fish. Aquat. Sci. 42: 521-528.

\title{
Migration of Postsmolt Atlantic Salmon, Salmo salar, Off Northeastern Newfoundland, As Inferred by Tag Recoveries in a Seabird Colony ${ }^{1}$
}

\author{
W. A. Montevecchi, D. K. Cairns'2, and V. L. Birt \\ Newfoundland Institute for Cold Ocean Science and Department of Psychology, Memorial University of Newfoundland, St. John's, Nfld. A1B $3 \times 9$
}

Montevecchi, W. A., D. K. Cairns, and V. L. Birt. 1988. Migration of postsmolt Atlantic salmon, Salmo salar, of northeastem Newfoundland, as inferred from tag recoveries in a seabird colony. Can. J. Fish. Aquat. Sci. 45: 568-571.

Northern gannets, Sula bassanus, and possibly other seabird species nesting on Funk island off northeastern Newfoundland preyed on postsmolt Atlantic salmon, Salmo salar. Salmon comprised less than $1 \%$ of 2928 regurgitated food samples collected from gannets at the colony. Ten smolt tags were recovered in and near the gannetry during August or September in 1984 through 1986. The tags were from smolts released 3-4 mo earlier in the Penobscot River (Maine) $(n=7)$ and one each from the Saint lohn River (New Brunswick) and the Lower Clyde and LaHave rivers (Nova Scotia). These recoveries provide evidence that postsmolt Atlantic salmon from rivers in New England, the Bay of Fundy, and the Atlantic coast of Nova Scotia migrate off eastern Newfoundland. This migratory pattern contrasts with that of postsmolts from the Gulf of St. Lawrence, which tend to move northwards along Newfoundland's west coast and through the Strait of Belle isle.

Des fous de Bassan (Sula bassanus) et peut-être d'autres oiseaux marins nichant sur l'île Funk, au large de la côte nord-est de Terre-Neuve, ont consommé des post-smolts de saumon de l'Atlantique (Salmo salar). Le saumon composait moins de $1 \%$ des 2.928 échantillons de nourriture régurgitée recueillis de fous de Bassan de la colonie. Dix étiquettes de smolts ont été récupérées dans la colonie et aux environs en août ou septembre de 1984 à 1986. Les étiquettes provenaient de smolts relâchés de 3 à 4 mo plus tôt dans la rivière Penobscot (Maine; $n=7$ ); trois autres étiquettes provenaient de la rivière Saint-Jean (Nouveau-Brunswick) ainsi que des rivières Lower Clyde et LaHave (Nouvelle-Écosse). Ces étiquettes récupérées prouvent que les post-smolts de saumon de l'Atlantique venant de rivières de la Nouvelle-Angleterre, de la baie de Fundy et de la côte atlantique de la Nouvelle-Ecosse traversent les eaux côtières occidentales de Terre-Neuve au cours de leur migration. Ce régime migratoire fait contraste avec celui des post-smolts du golfe du Saint-Laurent qui ont tendance à se diriger vers le nord le long de la côte ouest de Terre-Neuve et passent par le détroit de Belle Isle.

Received August 7, 1987

Reçu le 7 août 1987
le 12 novembre 1987

Accepted November 12, 1987

(j9382)

\begin{abstract}
Accepté le 12 novembre 1987
\end{abstract}
1Report 157 from the Newfoundland Institute for Cold Ocean Science, Memorial University of Newfoundland.
2Present address: Department of Fisheries and Oceans, Science Branch, Box 5030, Moncton, N.B. E1C 9B6. 
$\mathbf{T}$ he migratory patterns of Atlantic salmon, Salmo salar, in the Northwest Atlantic are not well understood (Kerswill and Keenleyside 1961; Cutting and Meister 1967; Stasko et al. 1973). The usual means of gathering information about the migration of salmon is the capture of tagged fish in commercial nets (Cutting and Meister 1967), but because there is no directed fishery for postsmolts, little is known about their movements (Huntsman 1938; Blair 1957; Murray 1958). The recapture of tagged postsmolts from rivers in the Gulf of St. Lawrence indicates that most of these fish depart the Gulf via the Strait of Belle Isle and that a small proportion travel south of Newfoundland via the Cabot Strait (Caron 1983; see also Kerswill 1955; Murray 1958; Belding and Préfontaine 1961). In this note we report observations on postsmolt Atlantic salmon migration based on a new data source: tag recoveries resulting from seabird predation. We also document the significance of predation by northern gannets, Sula bassanus, on Atlantic salmon.

\section{Methods}

During the course of investigations on the feeding ecology of northern gannets on Funk Island $\left(49^{\circ} 46^{\prime} \mathrm{N}, 53^{\circ} 11^{\prime} \mathrm{W}\right)$, Newfoundland, on 7-19 August 1984, 21 August - 14 September 1985, and 7-15 August 1986, 10 Atlantic salmon smolt tags were recovered. Tags were either attached to dead postsmolts regurgitated by gannets (1986) or on the ground in nesting areas of gannets, great black-backed gulls, Larus marinus, herring gulls, L. argentatus, and Atlantic puffins, Fratercula arctica $(1984,1985)$. During summer research visits in 1977$80,1982-83$, and 1987 , a small number of salmon were eaten by gannets, but no tags were found. Only during 1984-87 did we actively search for tags. The numerical percentage of Atlantic salmon in the diets of the gannets in these years was estimated from regurgitated food samples collected in nesting and roosting areas on Funk Island. Rates of travel at sea were coarsely estimated by calculating straight-line distances between the mouths of rivers into which the tagged smolts were released and dividing these by the number of days in the release-recovery intervals.

\section{Results}

All tags were from hatchery smolts released into rivers in Maine, New Brunswick, and Nova Scotia during the previous late April - early May (Table 1). Seven of the 10 recoveries were from fish released into the Penobscot River (Maine), and tags from salmon from this river were recovered in each of the years from 1984 through 1986 . Using a release date of 8 May (Table 1), the $\ddot{X} \pm$ SD release-recovery interval was $102.1 \pm 10.1 \mathrm{~d}($ range $=92-127 \mathrm{~d})$. On the basis of straightline sea distances between the mouths of rivers into which tagged smolts were released and Funk Island (Fig. 1), the postsmolts would have traveled a $\bar{X} \pm$ SD of $19.2 \pm 2.2$ $\mathrm{km} \cdot \mathrm{d}^{-1}$ (range $\left.=15.7-21.7 \mathrm{~km} \cdot \mathrm{d}^{-1}\right)$.

Gannets preyed on Atlantic salmon that had approximate total lengths of $25-30 \mathrm{~cm}$. From 1984 through 1986, salmon, including fish and tags, made up less than $2 \%$ (17/996) of the food samples. During 1977-80, 1982-83, and 1987, only 6 salmon $(0.3 \%)$ were found among 1932 regurgitated fish samples. In all years combined, salmon comprised $0.8 \%$ of the regurgitated food samples identified (23/2928). In 1986, 33\% $(4 / 12)$ of the salmon found in the food samples were tagged. These tags were removed from fresh fish regurgitated by gannets and were thus obtained within hours of predation.

\section{Discussion}

Our data indicate that some postsmolts from rivers in Maine, the Bay of Fundy, and the Atlantic Coast of Nova Scotia migrate off Newfoundland's east coast. Consistent with this finding, a tag from a salmon smolt from the St. Croix River on the Maine - New Brunswick border was recovered from a common murre, Uria aalge, at Witless Bay in eastern Newfoundland on 13 July 1984 , approximately 2 mo after its release (D. Methven and J. Piatt, Newfoundland Institute for Cold Ocean Science, Memorial University of Newfoundland, St. John's, Nfld., pers. comm.). These movement patterns contrast with those of postsmolts from the Gulf of St. Lawrence, which tend to migrate northwards through the Strait of Belle Isle (Caron 1983).

Our estimate of the mean rate of daily movement at sea is most probably low for at least four reasons: (1) released fish usually take days or weeks to depart rivers and estuaries before the onset of migration (Stasko et al. 1973); (2) it is not likely that migrating fish take straight-line routes; (3) many days may have elapsed between the time birds preyed on the marked fish and the dates on which we subsequently recovered detached tags; (4) the release-recovery interval of the tag obtained from the murre's stomach indicate that much faster rates of movements are possible (see also Stasko et al. 1973).

Our recovery of tags from fresh fish from the Penobscot River and from the LaHave River on 8 August 1986 indicates that some postsmolts from different rivers were in the vicinity of Funk Island simultaneously and suggests that fish from different rivers travel together or in proximity at sea. Gannets, however, have a foraging range of more than $100 \mathrm{~km}$ (Montevecchi and Porter 1980; Kirkham et al. 1985), so these fish may have been spatially well separated. In contrast, Huntsman (1938) suggested that salmon from different rivers might have distinct migratory chronologies and routes. The postsmolts may have also been close to schools of other surface schooling pelagic fish: of the 12 fresh salmon found in gannet regurgitations in 1986, 6 were in regurgitations that also contained mackerel, Scomber scombrus (3), herring, Clupea harengus (2), and Atlantic saury, Scomberesox saurus (1). Gannets plunge dive for prey that occur in about the upper $5 \mathrm{~m}$ of the water column, where postsmolts are likely to swim (Huntsman 1938).

The salmon captured by gannets on Funk Island were smaller than most prey taken by these birds (Montevecchi and Barrett 1987; W. A. Montevecchi, in prep.). Five of the tags were recovered in nesting areas of great black-backed gulls, herring gulls, and Atlantic puffins. Although it is possible that all of these birds prey on small salmon, the tags may have been transported to these nesting areas from the gannetry by gulls that scavenge food scraps from the gannets. The puffins $(\sim 0.4$ $\mathrm{kg}$ ) are the smallest of the potential predators and would not be able to take fish as large as could murres, gulls, or gannets.

Salmon was a very minor component of the gannets' diet; these seabirds eat very few of these fish. Salmonids are considered to be preyed on much more extensively by other avian predators, such as cormorants Phalacrocorax spp., common mergansers, Mergus merganser, and belted kingfishers, $M e$ gaceryle alcyon (e.g. Elson 1962, 1975; Wood 1985; Kennedy and Johnston 1987), but the only other salmon tag recovery associated with avian predation that we could find in the literature, involved an osprey, Pandion haliaetus (Blair 1956). Salmon tags have also been recovered from cormorants and 
TABLE 1. Atlantic salmon tag recoveries made in 1984-86 in and near the colony of northern gannets on Funk Island, Newfoundland.

\begin{tabular}{|c|c|c|}
\hline River of origin & Release date & Recovery date \\
\hline $\begin{array}{l}\text { Lower Clyde River, } \\
\text { Nova Scotia }\end{array}$ & May 1984 & 18 August 1984 \\
\hline $\begin{array}{l}\text { Saint John River, } \\
\text { New Brunswick }\end{array}$ & 8 May 1984 & 19 August 1984 \\
\hline $\begin{array}{l}\text { Penobscot River, } \\
\text { Maine }\end{array}$ & $\begin{array}{l}\text { Late April - } \\
\text { early May } 1984\end{array}$ & 19 August 1984 \\
\hline $\begin{array}{l}\text { Penobscot River at } \\
\text { Eddington, Maine }\end{array}$ & $\begin{array}{l}\text { Late April - } \\
\text { early May } 1984\end{array}$ & 19 August 1984 \\
\hline $\begin{array}{l}\text { Penobscot River, east branch, } \\
\text { at Medway, Maine }\end{array}$ & $\begin{array}{l}\text { Late April - } \\
\quad \text { early May } 1984\end{array}$ & 19 August 1984 \\
\hline $\begin{array}{l}\text { Penobscot River at } \\
\text { Eddington, Maine }\end{array}$ & Early May 1985 & 12 September 1985 \\
\hline $\begin{array}{l}\text { LaHave River, } \\
\text { Nova Scotia }\end{array}$ & May 1986 & 8 August 1986 \\
\hline Penobscot River, Maine & 8 and 9 May 1986 & 8 August 1986 \\
\hline Penobscot River, Maine & 8 and 9 May 1986 & 9 August 1986 \\
\hline Penobscot River, Maine & 8 and 9 May 1986 & 10 August 1986 \\
\hline
\end{tabular}

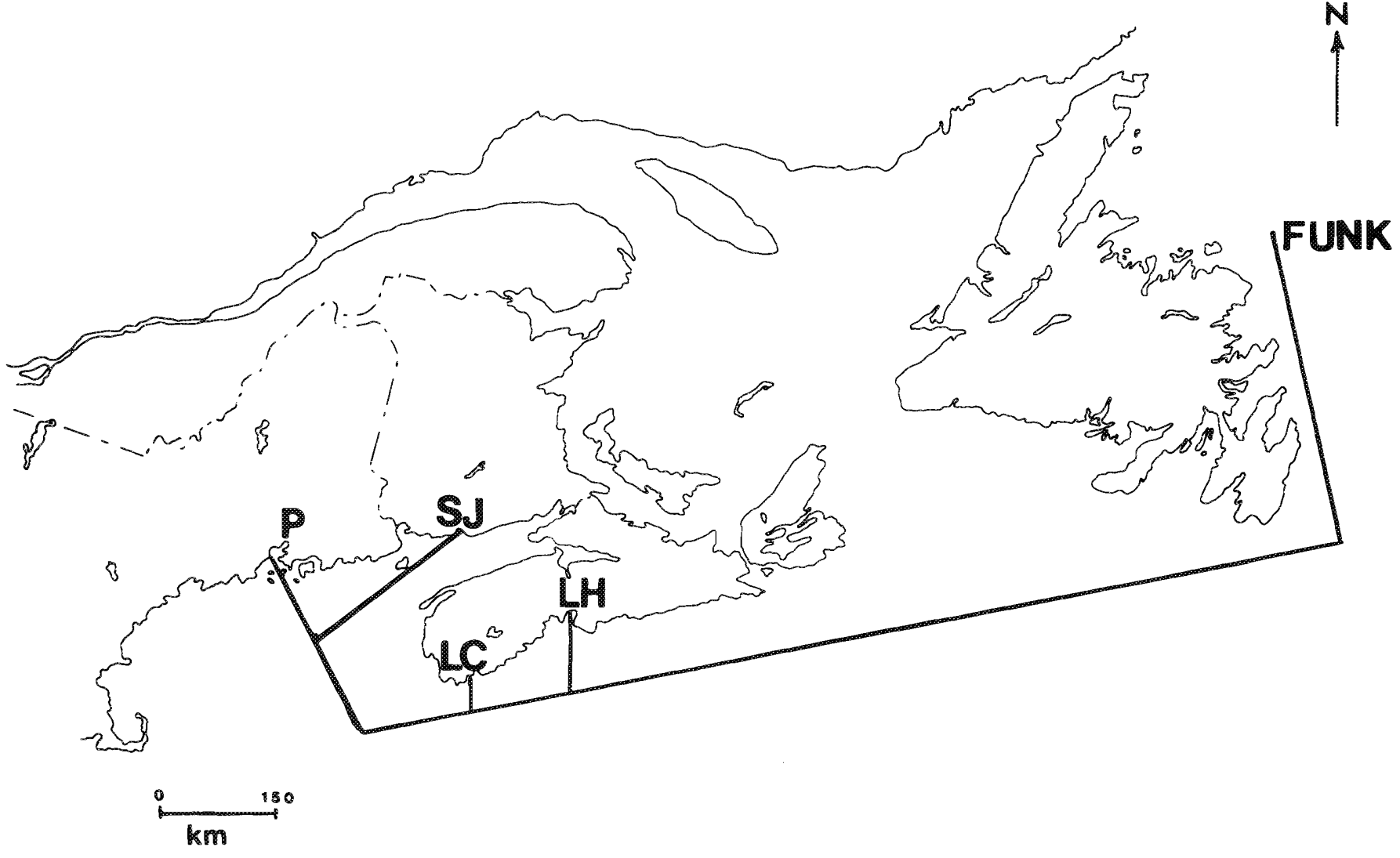

FIG. 1. Rivers of origin and straight-line distances of travel at sea by postsmolt Atlantic salmon whose tags were recovered in the seabird colonies on Funk Island (FUNK), Newfoundland. $\mathrm{P}=$ Penobscot River, $\mathrm{SJ}=$ Saint John River, $\mathrm{LC}=\mathrm{Lower} \mathrm{Clyde}$ River, $\mathrm{LH}=\mathrm{LaHave}$ River.

mergansers, although these data are yet to be published (G. Farmer, Department of Fisheries and Oceans, Halifax, N.S., pers. comm.; C. C. Wood, Pacific Biological Station, Nanaimo, B.C., pers. comm.). Preliminary plans are also being made to use metal detectors to search for metallic salmon tags in cormorant colonies in British Columbia (A. E. Burger, Bamfield Marine Station, Nanaimo, B.C., pers. comm.).

Owing to trophic interactions between seabirds and fish, the feeding and reproductive patterns of marine birds can be used to assess fish stock distribution and availability, as well as mesoscale oceanography (e.g. Ashmole and Ashmole 1968; Boersma 1979; Berruti 1987; Furness and Monaghan 1987; Montevecchi et al. 1987). The present report indicates that marine birds can also serve other functions in monitoring fisheries, and comprehensive studies of the trophic interactions of seabirds will certainly reveal more. 


\section{Acknowledgements}

We thank $J$. Hutchings, T. Birt, and G. Farmer for information on Atlantic salmon life history and migration, K. Bredin for field assistance, A. E. Burger, R. J. Gibson, J. Hutchings, D. Methven, and C. C. Wood for helpful comments on the manuscript, and the Newfoundland and Labrador Wildlife Division for permission to carry out research on Funk Island, which is a Provincial Ecological Reserve. Research was supported by an NSERC Individual Operating Grant (A0687) and 1985 and 1986 Subvention Grants from the Department of Fisheries and Oceans.

\section{References}

AsHMOLE, M. J., AND N. P. ASHMOLE. 1968. The use of food samples from sea birds in the study of seasonal variation in the surface fauna of tropical oceanic areas. Pac. Sci. 22: 1-10.

Belding, D. L., AND G. Préfontaine. 1961. A report on the salmon of the North Shore of the Gulf of St. Lawrence and of the northeastern coast of Newfoundland. Contrib. Dep. Pech. Que. No. 82: $104 \mathrm{p}$.

BERRUTI, A. 1987. The use of cape gannets Morus bassanus in management of the purse-seine fishery of the Western Cape. Ph.D. thesis, University of Natal (Pietermaritzburg), South Africa. 304 p.

BLAR, A. A. 1956. Atlantic salmon tagged in east coast Newfoundland waters at Bonavista. J. Fish. Res. Board Can. 13: 219-232.

1957. Salmon tagging at Francis Harbour Bight, Labrador. J. Fish. Res. Board Can. 14: 135-140.

Boersma, P. D. 1979. Breeding patterns of Galapagos penguins as an indicator of oceanographic conditions. Science (Wash., DC) 200: 14811483.

Caron, F. 1983. Migration vers L'Atlantique des post-saumoneaux (Salmo salar) du Golfe du Saint-Laurent. Naturaliste can. (Rev. Ecol. Syst.) 110: 223-227.

Cutting, R. E., AND A. L. Meister. 1967. Marine migration of Atlantic salmon kelts tagged in Maine. Int. Comm. NW Atl. Redbook. Part 3: $58-65$.

ELSON, P. F. 1962. Predator-prey relationships between fish-eating birds and
Atlantic salmon. Bull. Fish. Res. Board Can. 58.

1975. Atlantic salmon rivers, smolt production and optimal spawning: an overview of natural production. Int. Aul. Salmon J. Spec. Publ. Ser. 6: 96-119.

Furness, R. W., AND P. Monoghan. 1987. Seabird ecology. Blackie, Glasgow, Scotland. $164 \mathrm{p}$.

Huntsman, A. G. 1938. Sea movements of Canadian Atlantic salmon kelts. J. Fish. Res. Board Can. 4: 96-135.

KENNEDY, G. J. A., AND P. M. JOHNSTON. 1987. A review of salmon research on the River Bush. Proc. 17th Conf. Inst. Fish. Manage., Sept. 1986, Coleraine, $\mathbf{N}$. Ireland.

KERSWILL, C. J. 1955. Recent developments in Atlantic salmon research. Atl. Salmon. J. No. 1: 26-30.

KERSWILL, C. J., AND M. H. A. KeENLEYSIDE. 1961. Canadian salmon caught off Greenland. Nature (Lond.) 192: 279.

KIRKHAM, I. R., P. L. MCLAREN, AND W. A. MonteVECChi. 1985. The food habits and distribution of northern gannets, Sula bassamus, off eastern Newfoundland and Labrador. Can. J. Zool. 63: 181-188.

MONTEVECCHI, W. A., AND R. T. BARRETT. 1987. Prey selection by gannets at breeding colonies in Norway. Ornis Scand. 18: 319-322.

MONTEVECCHI, W. A., V. L. BIRT, AND D. K. CAIRNS. 1987. Dietary changes of seabirds associated with local fishery failures. Biol. Oceanogr. 5. (In press)

MonteVeCCHI, W. A., AND J. M. PORTER. 1980. Parental investments by seabirds at the breeding area with emphasis on northern gannets, p. 323365. In J. Burger, B. Olla, and $\mathrm{H}$. Winn [ed.] Behavior of marine animals: current perspectives in research. Vol. 4. Seabirds. Plenum Press, New York, NY.

MURRAY, A. R. 1958. Survival and utilization of Atlantic salmon of the Little Codroy River, Newfoundland. Fish. Res. Board Can. Prog. Rep. Atl. Coast Stn. No. 70: 16-22.

Stasko, A. B., A. M. SUtTERlin, S. A. Rommel JR., AND P. F. Elson. 1973. Migration-orientation of Atlantic salmon (Salmo salar L.). Int. Atl. Salmon Symp. Spec. Publ. Ser. 4, No. 1: 119-137.

WooD, C. C. 1985 . Aggregative response of common mergansers (Mergus merganser): predicting flock size and abundance on Vancouver Island salmon streams. Can. J. Fish. Aquat. Sci. 42: 1259-1271.

\title{
Dependence of Lake Oxygen Depletion Rates on Maximum Oxygen Storage in a Partially Meromictic Lake in Alberta ${ }^{1}$
}

\author{
Annette M. Trimbee and E. E. Prepas \\ Department of Zoology, University of Alberta, Edmonton, Alta. T6C $2 E 9$
}

\begin{abstract}
Trimbee, A. M., and E. E. Prepas. 1988. Dependence of lake oxygen depletion rates on maximum oxygen storage in a partially meromictic lake in Alberta. Can. J. Fish. Aquat. Sci. 45: 571-576.

Areal rates of hypolimnetic oxygen depletion (AHOD) and winter oxygen depletion (AWOD) varied considerably from year to year in a partially meromictic lake (Narrow Lake) in central Alberta. AHOD ranged from 0.222 to $0.522 \mathrm{~g} \mathrm{O}_{2} \cdot \mathrm{m}^{-2} \cdot \mathrm{d}^{-1}$ over four summers and AWOD ranged from 0.354 to $0.614 \mathrm{~g} \mathrm{O}_{2} \cdot \mathrm{m}^{-2} \cdot \mathrm{d}^{-1}$ over three winters. AHOD was positively correlated with maximum storage of dissolved oxygen $\left(\mathrm{O}_{2}\right)$ at the onset of summer thermal stratification $(P<0.05)$. Similarly, AWOD was higher in years when mixing was more complete and maximum $\mathrm{O}_{2}$ storage at freeze-up was higher. These results suggest that the prediction of $\mathrm{O}_{2}$ depletion rates for lakes with year-to-year variation in maximum $\mathrm{O}_{2}$ storage can be improved if maximum $\mathrm{O}_{2}$ storage after lake mixing is considered in addition to other factors known to influence $\mathrm{O}_{2}$ depletion rates such as lake productivity and morphometry.
\end{abstract}

'A contribution to the Narrow Lake Project based at the Meanook Biological Research Station. 